\title{
The hypocrisy of Canada's prostitution legislation
}

Previously published at www.cmaj.ca

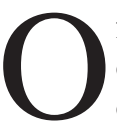
ften described as the world's oldest profession, the exchange of sex for money has always existed and will continue to exist worldwide. For many, the sex industry evokes a sense of moral unease, and divides feminists and society alike on whether it is an oppression and commodification of women, or a woman's right and choice to sell her body. Canada's federal legislation reflects this divide: The buying and selling of sex among consensual adults has always been legal, yet criminal code provisions on communicating, procuring, bawdy houses and living off the avails of prostitution make it virtually impossible to work legally in safer indoor settings.

Against this backdrop, the numbers of missing and murdered women continue to swell in Canadian cities and streetinvolved women engaged in sex work experience some of the worst health outcomes in our society, including drugrelated harms, trauma, and HIV and other sexually transmitted infections. ${ }^{1-4}$ Standardized mortality rates among female street-based sex workers are higher than any other population of women in North America, with homicide being the most common cause of death.

Sadly, there are multiple examples of convictions of serial murderers of sex workers over the last decade in North America and the United Kingdom, and ongoing concerns remain of potential serial murderers in Edmonton, Winnipeg and along the "Highway of Tears" in Northern British Columbia. The recent convictions for the gruesome homicides of women on the streets of Vancouver and Seattle - the largest serial murders in Canadian and American history should be a vivid and chilling reminder.

Importantly, growing peer-reviewed research published in some of the top medical journals now suggest that enforcement of criminal sanctions targeting sex work, including communicating in public spaces, displaces sex workers to isolated alleys and industrial settings away from health and support services. ${ }^{1-4}$ Enforced displacement and lack of access to safer indoor work environments independently increase sex workers' risk of physical violence and rape, and reduces their ability to safely negotiate condom use with clients, ${ }^{1,2}$ thereby protecting themselves from sexually transmitted infections and unwanted pregnancies. Qualitative evidence further describes how criminal sanctions limiting sex workers' ability to regulate safer industry practices (e.g., create unions, safer indoor work spaces. etc.) compound health-related risks. ${ }^{3}$

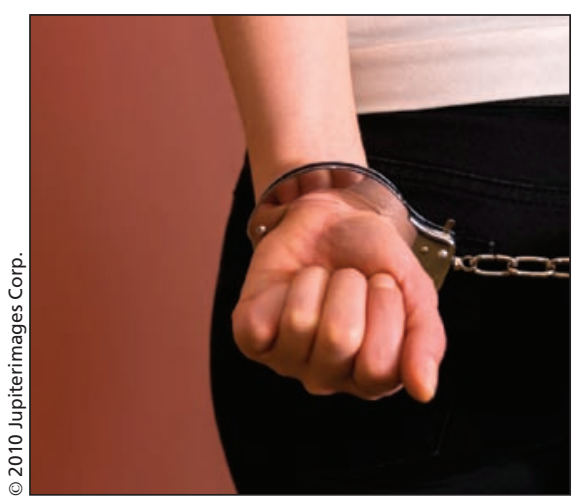

Globally, evidence-based public health research is being used in calls to remove criminal sanctions targeting sex work; one such call even came from the United Nations Secretary-General Ban $\mathrm{Ki}$-moon. Yet in Canada this public health policy gap has been met with scaled up enforcement-based efforts targeting sex workers and their clients. According to the Canadian Centre for Justice Statistics, ${ }^{5}$ following the enactment of the 1985 'communicating code' legislation designed to remove the visible presence of sex work, annual prostitution arrests increased nearly 10 -fold from 1255 arrests in 1985 to 10457 arrests in 1987. These rates have remained constant at about 10000 arrests per year, with 97\% occurring in Vancouver, Toronto and Montréal.

Despite three separate parliamentary sub-committees on prostitution since the mid 1980s, sex workers and human rights experts are now being forced to challenge the criminal sanctions through the courts, as a violation of the Charter of Rights and Freedom.

Now, as we wait for the Ontario Supreme Court decision on one challenge, the federal government has taken another backward step, this time by reclassifying the Criminal Code on "keeping a bawdy house" (a place kept for the purpose prostitution) making it a serious crime with a maximum sentence of five years imprisonment. ${ }^{6}$ This new Criminal Code regulation, introduced without Parliamentary debate, is in blatant disregard of the evidence and has the concerning risk of pushing sex workers further underground and outside the public health umbrella. In perhaps the saddest reflection of this public health policy gap, in 2008 sex workers in Edmonton began giving samples of their DNA to a community agency and RCMP network to ensure their bodies would be identified in case of future harm.

While rigorous evaluation of legal policy approaches to sex work remains critical, it is also time for government and policy makers to take into account the evidence of the failures of the criminalized approach to sex work on health and human rights in Canadian society.

\section{Kate Shannon PhD \\ Assistant professor \\ Department of Medicine \\ University of British Columbia \\ Vancouver, BC}

\section{REFERENCES}

1. Shannon K, Strathdee SA, Shoveller J, et al. Structural and environmental barriers to condom use negotiation with clients among female sex workers: Implications for HIV prevention strategies and policy. Am J Public Health 2009;99:659-65.

2. Shannon K, Kerr T, Strathdee SA, et al. Prevalence and structural correlates of gender-based violence in a prospective cohort of female sex workers. $B M J$ 2009;339:b2939.

3. Rekart ML. Sex-work harm reduction. Lance 2005;366:2123-34.

4. Goodyear M, Cusick L. Protection of sex workers. BMJ 2007;334:52-3.

5. Duchesne D. Street prostitution in Canada. Ottawa (ON): Statistics Canada; 2002. Cat. no. 85-002-XPE

6. Perreaux L. Tory legislation takes aim at brothels and bookies. The Globe and Mail [Toronto] 2010 Aug. 5. Sect A:6 